\title{
The Effects of Primary Oxy-Salts on Anodizing Magnesium Alloy AZ91D
}

\author{
Dingchuan Xue a,\#, Yeoheung Yun, ${ }^{\mathrm{b},}$, Brian H. Halsall, William Vanooij ${ }^{\mathrm{a}, \mathrm{d}}$, Mark J. Schulz ${ }^{\mathrm{e}}$ and \\ Vesselin Shanov ${ }^{a}$
}

${ }^{a}$ Dept of Chemical and Materials Engineering, University of Cincinnati, Cincinnati, OH 45221, USA

${ }^{b}$ Dept of Bio-Engineering, North Carolina Agricultural \& Technical State University, Greensboro, NC 27411, USA

${ }^{c}$ Dept of Chemistry, University of Cincinnati, Cincinnati, OH 45221, USA

${ }^{d}$ Ecosil Technologies LLC, Fairfield, OH 45014, USA

${ }^{e}$ Dept of Mechanical Engineering, University of Cincinnati, Cincinnati, OH 45221, USA

\begin{abstract}
Anodization is known to be an effective way to slow down the initial corrosion rate of magnesium $(\mathrm{Mg})$ and its alloys. Here, we investigated the specific use of oxy-salts to improve the corrosion resistance of anodizing coatings. Oxy-salts of silicate, phosphate, and carbonate were added separately to a sodium hydroxide alkaline electrolyte used to anodize $\mathrm{Mg}$ alloy AZ91D. The process was investigated in terms of anodizing behavior, the surface properties, and the corrosion behavior of AZ91D. Anodizing AZ91D using the silicate- containing electrolyte generated sparks, and produced a thicker and more corrosion-resistant layer than the other oxy-salts. In the process, $\mathrm{MgO}$ and $\mathrm{SiO}_{2}$ formed $\mathrm{Mg}_{2} \mathrm{SiO}_{4}$ at high temperatures. Coatings from the phosphate- and carbonate- containing electrolyte anodizations did not contain phosphorus or carbon. We also studied the effects of silicate concentration on the corrosion resistance and properties of the surface.
\end{abstract}

Received on 02-03-2014

Accepted on 01-05-2014

Published on 07-07-2014

Keywords: Anodization, corrosion, AZ91D, primary oxy-salt.

\section{INTRODUCTION}

With excellent mechanical properties, lightweight magnesium (Mg) and its alloys have become popular candidates for industrial applications. Recently, $\mathrm{Mg}$ is also being evaluated as an implant material due to its biodegradability, biocompatibility, and bone-like physical properties [1-4]. In industrial and biological applications, the low corrosion resistance of $\mathrm{Mg}$ is a drawback since $\mathrm{Mg}$ loses strength and toughness when it corrodes. In biomedical applications, $\mathrm{Mg}$ implants may degrade too quickly, especially at the initial stage of implantation. Therefore, corrosion protection is needed when $\mathrm{Mg}$ is considered for industrial and biomedical applications.

Anodization is one of the effective approaches used to slow down the corrosion rate of $\mathrm{Mg}$. Many studies have

"Fort-IRC Building Room \# 119, 1601 E. Market St, Greensboro, NC 27411, USA; Tel: 001-336-256-1151 ext. 2010; Fax: 001-336-256-1153;

E-mail: yyun@ncat.edu

${ }^{\#}$ Currently holding a position at TDK Headway Technologies Inc. investigated various aspects of anodization of $\mathrm{Mg}$ including the effects of different substrate materials [5-7], anodizing process parameters [7-9], and electrolytes [9-11]. Currently, alkaline electrolyte is used most. Popular additives to the alkaline electrolyte are fluoride [10,12], metallic salts [13-15], and oxy-salts such as silicate, phosphate, carbonate, and borate $[13,14,16-19]$. The additives form insoluble $\mathrm{Mg}$ compounds, such as $\mathrm{Mg}$ oxide and hydroxide, on the surface of the $\mathrm{Mg}$, improving its corrosion resistance [8, 20, 21]. However, previous studies used chemical mixtures, and the effects of specific chemicals have been given sparse attention. Chai et al. [22] investigated the specific addition of silicate, phosphate, aluminate and molybdate as secondary oxy-salts in addition to the primary oxy-salt of borate in the alkaline electrolyte. However, few studies have examined the effects of adding silicate, phosphate, and carbonate on anodizing $\mathrm{Mg}$ as the primary oxy-salt. Here, sodium silicate, sodium phosphate, and sodium carbonate were added separately as the primary oxy-salts to a sodium hydroxide alkaline electrolyte, and compared. The concentration of 
Table 1: Anodization Systems and Symbols Used in this Work

\begin{tabular}{|c|c|c|c|c|}
\hline \multirow{2}{*}{ Symbols } & \multicolumn{2}{|l|}{ Electrolyte } & \multicolumn{2}{|c|}{ Anodizing parameters } \\
\hline & Composition & $\mathrm{pH}$ & Current $\left(\mathrm{mA} / \mathrm{cm}^{2}\right)$ & Time (min) \\
\hline A0 & $2 \mathrm{M} \mathrm{NaOH}$ & 13.02 & 10 & 30 \\
\hline $\mathrm{A} 1$ & $2 \mathrm{M} \mathrm{NaOH}+0.05 \mathrm{M} \mathrm{Na}_{2} \mathrm{SiO}_{3}$ & 13.02 & 10 & 30 \\
\hline A2 & $2 \mathrm{M} \mathrm{NaOH}+0.05 \mathrm{M} \mathrm{Na}_{3} \mathrm{PO}_{4} \cdot 12 \mathrm{H}_{2} \mathrm{O}$ & 13.02 & 10 & 30 \\
\hline A3 & $2 \mathrm{M} \mathrm{NaOH}+0.05 \mathrm{M} \mathrm{Na}_{2} \mathrm{CO}_{3} \cdot 10 \mathrm{H}_{2} \mathrm{O}$ & 13.02 & 10 & 30 \\
\hline $\mathrm{A} 1$ & $2 \mathrm{M} \mathrm{NaOH}+0.05 \mathrm{M} \mathrm{Na}_{2} \mathrm{SiO}_{3}$ & 13.02 & 10 & 30 \\
\hline A1-1 & $2 \mathrm{M} \mathrm{NaOH}+0.15 \mathrm{M} \mathrm{Na}_{2} \mathrm{SiO}_{3}$ & 13.16 & 10 & 30 \\
\hline A1-2 & $2 \mathrm{M} \mathrm{NaOH}+0.5 \mathrm{M} \mathrm{Na}_{2} \mathrm{SiO}_{3}$ & 13.2 & 10 & 30 \\
\hline A1-3 & $2 \mathrm{M} \mathrm{NaOH}+3 \mathrm{M} \mathrm{Na}_{2} \mathrm{SiO}_{3}$ & 13.9 & 10 & 30 \\
\hline
\end{tabular}

silicate was optimized by characterizing the surface and its ability to inhibit corrosion.

\section{EXPERIMENTAL}

AZ91D was from ACT Test Panels Technologies, and machined into pieces $15 \mathrm{~mm} \times 15 \mathrm{~mm} \times 3 \mathrm{~mm}$. The machined samples were embedded in epoxy resin (Buehler Inc.). The area exposed was $2.25 \mathrm{~cm}^{2}$. The epoxy-sealed samples were then polished up to 800 grit, rinsed with ethanol and DI water, and air-gun dried before use. The machined, polished and cleaned samples are named "fresh AZ91D" in this work.

The detailed experimental solutions are listed in Table 1, and were mixed well before use. Each prepared solution was 100 $\mathrm{mL}$. The symbols for each system will be used in this paper. The power supply (0-3000 V, 0-40 mA) was from Circuit Specialist Inc. The anode (AZ91D) and cathode (platinum hoop, Fisher Scientific) were $5 \mathrm{~cm}$. apart. Anodizing was done at a constant current density of $10 \mathrm{~mA} / \mathrm{cm}^{2}$, and the bath was stirred throughout the process. Finally, the anodized sample was rinsed with distilled water and dried with an air gun. The cell temperature and voltage were recorded.

Electrochemical tests were used to study the corrosion behavior using a $0.15 \mathrm{M} \mathrm{NaCl}$ solution as a corrosive environment at room temperature. An SR 810 frequency response analyzer and Gamry $\mathrm{PCl} 4 / 300$ potentiostat comprised the electrochemical test equipment. $\mathrm{An} \mathrm{Ag} / \mathrm{AgCl}$ in saturated potassium chloride electrode and platinum mesh functioned as the reference and counter electrodes, respectively. The distance between the electrodes was fixed during all tests. Open Circuit Potential (OCP) measurements were made 1 and $10 \mathrm{hrs}$ after immersion. A range of corrosion potential, $\left(E_{\text {corr }}\right) \pm 0.25 \mathrm{~V}$ and $1 \mathrm{mV} / \mathrm{s}$ scan rate was applied in the DC polarization test. The experimental curves were fitted by the nonlinear least squares curve fitting tool, Gamry Echem Analyst, yielding the results of the corrosion potential $\left(E_{\text {corr }}\right)$, corrosion current density $\left(I_{\text {corr }}\right)$ and corrosion rate. The frequency used was from $10^{5} \mathrm{~Hz}$ to $0.2 \mathrm{~Hz}$ in the electrochemical impedance spectroscopy (EIS) test. Several equivalent circuit models using the nonlinear least squares curve fitting tool, Gamry Echem Analyst, were tried to fit the experimental results and the best possible fit was selected. A Philips XL 30 environmental scanning electron microscope (ESEM) was used to characterize the morphology. Energydispersive X-ray spectroscopy (EDX) was used to investigate the chemical composition. During the EDX analysis, areas were measured at $100 \mathrm{X}$ magnification, a $15 \mathrm{kV}$ accelerating voltage, and 20 seconds collecting time.

The contact angle is the angle at which a liquid/vapor interface meets the solid surface. Contact angle is used to characterize and observe the coatings on metal. Contact angle measurements were carried out on a contact angle goniometer VCA2000, manufactured by AST products, Inc, Billeriaca, MA, USA. Water was injected onto the coatings by a syringe. The results of contact angle were obtained by applying goniometer software.

\section{RESULTS}

\subsection{The Effects of Oxy-Salts on Anodization}

\subsubsection{The Effects on Anodization Behavior}

Figure 1, shows that $A 0(A), A 1(B), A 2(C)$ and $A 3(D)$ had different anodization behaviors. Low terminating voltages for A0, A2, A3 and a high terminating voltage for A1 were found. The voltages of $A 0, A 2$, and $A 3$ immediately jumped to 7-9 V within a few seconds and then dropped to around $4 \mathrm{~V}$. However, the A1 voltage increased dramatically to $60 \mathrm{~V}$ in a few seconds. Uniform sparking started at about $45 \mathrm{~V}$.

\subsubsection{The Effects on Surface Characterization}

The morphology of the coating produced from the $2 \mathrm{M} \mathrm{NaOH}$ only electrolyte is shown in Figure 2A. Figure 2B shows that adding silicate to the $2 \mathrm{M} \mathrm{NaOH}$ electrolyte had a strong effect on the morphology of the coating. Adding phosphate, Figure 2C, and carbonate, Figure 2D, barely affected the coating morphology. Adding silicate created volcano-like rough areas on the surface. The relatively rough areas had larger, but less porosity (number of pores) compared to relatively smooth areas. The rough area has about 4 pores per $4 \mathrm{E}+04 \mathrm{um}^{2}$. The smooth area has about 10 pores per 4 $\mathrm{E}+04 \mathrm{um}^{2}$. As seen in Table 2, all four samples of A0, A1, A2, 

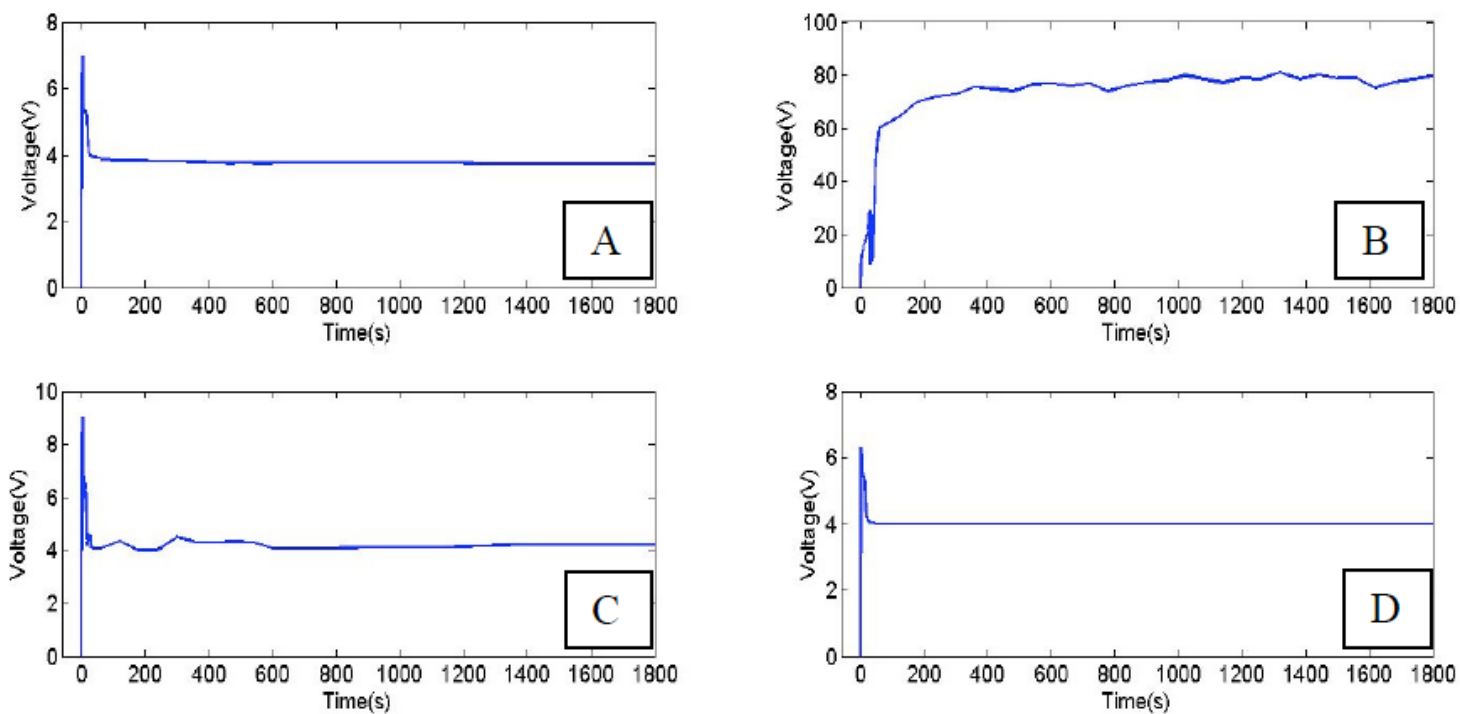

Figure 1: Anodizing behavior of different primary oxy-salts additions at $10 \mathrm{~mA} / \mathrm{cm}^{2}$ for $30 \mathrm{~min}$. (A) $2 \mathrm{M} \mathrm{NaOH}(\mathrm{A} 0),(B) 2 \mathrm{M} \mathrm{NaOH}+0.05 \mathrm{M}$ $\mathrm{Na}_{2} \mathrm{SiO}_{3}(\mathrm{~A} 1)$, (C) $2 \mathrm{M} \mathrm{NaOH}+0.05 \mathrm{M} \mathrm{Na}_{3} \mathrm{PO}_{4}(\mathrm{~A} 2)$, (D) $2 \mathrm{M} \mathrm{NaOH}+0.05 \mathrm{M} \mathrm{Na}_{2} \mathrm{CO}_{3}($ A3) .
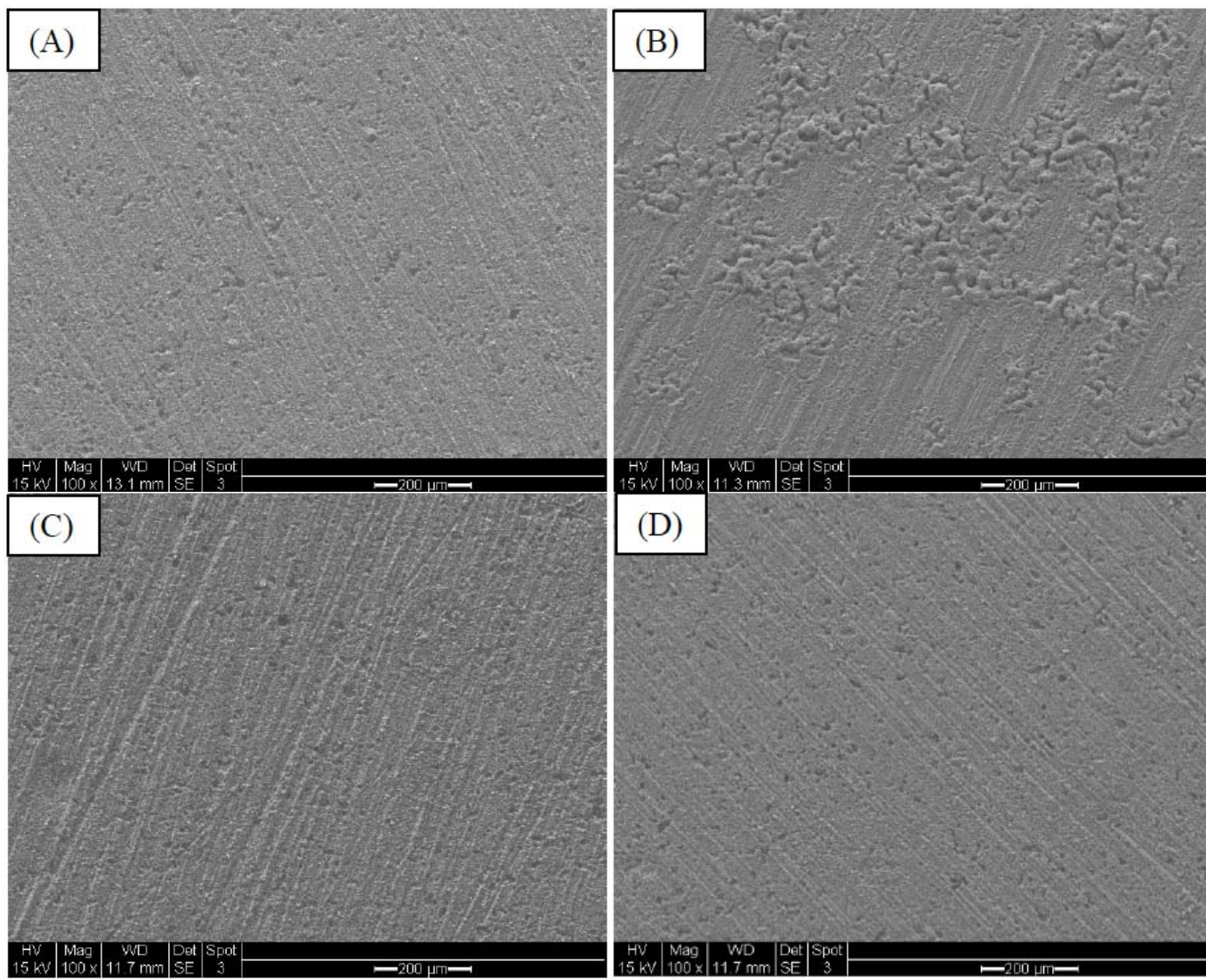

\section{(D)}

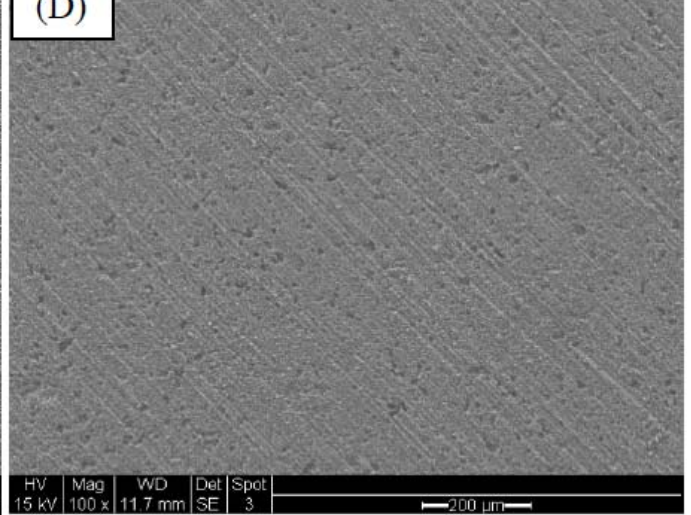

Figure 2: Morphology of anodized coatings with different primary oxy-salt additions at $10 \mathrm{~mA} / \mathrm{cm}^{2}$ for $30 \mathrm{~min} .(\mathbf{A}) 2 \mathrm{M} \mathrm{NaOH}(\mathrm{AO})$, (B) $2 \mathrm{M} \mathrm{NaOH}$ $+0.05 \mathrm{M} \mathrm{Na}_{2} \mathrm{SiO}_{3}(\mathrm{~A} 1),(\mathbf{C}) 2 \mathrm{M} \mathrm{NaOH}+0.05 \mathrm{M} \mathrm{Na}_{3} \mathrm{PO}_{4}(\mathrm{~A} 2)$, (D) $2 \mathrm{M} \mathrm{NaOH}+0.05 \mathrm{M} \mathrm{Na}_{2} \mathrm{CO}_{3}$ (A3).

and $\mathrm{A} 3$ had similar $\mathrm{O}$ concentrations. Mg dropped from 85.5 at. \% in the fresh AZ91D to around 50.0 at. \% in the anodized samples. Si was found as 2.0 at. \% in $A 1$. P and $C$ were not found in the A2 and A3 systems. Zn was not listed in Table 2 since it was below 1.0 at. \% in the fresh AZ91D and even lower in anodized samples.

\subsubsection{The Effects on Corrosion Behaviors}

In Figures $\mathbf{3 A}$ and $\mathbf{B}$, all the anodized samples had higher corrosion impedances than the fresh AZ91D during the 1 hour and 10 hour EIS tests. In the first hour, Figure $\mathbf{3 A}$, all of the anodized samples are better than the untreated alloy. At certain phase angle, the absolute impedance of untreated 
Table 2: Detailed Surface Element Information in Atom Percent of Anodized Coatings from Different Primary Oxy-Salts Addition Electrolytes at $10 \mathrm{~mA} / \mathrm{cm}^{2}$ for $30 \mathrm{~min}$. Fresh AZ91D; $2 \mathrm{M} \mathrm{NaOH}(\mathrm{AO}) ; 2 \mathrm{M} \mathrm{NaOH}+0.05 \mathrm{M} \mathrm{Na}_{2} \mathrm{SiO}_{3}(\mathrm{~A} 1) ; 2 \mathrm{M} \mathrm{NaOH}+0.05 \mathrm{M}$ $\mathrm{Na}_{3} \mathrm{PO}_{4}(\mathrm{~A} 2) ; 2 \mathrm{M} \mathrm{NaOH}+0.05 \mathrm{M} \mathrm{Na}_{2} \mathrm{CO}_{3}(\mathrm{~A} 3)$

\begin{tabular}{|c|c|c|c|c|c|}
\hline & AZ91D & A0 & A1 & A2 & A3 \\
\hline \hline O & 5.2 & 44.6 & 43.2 & 48.7 & 40.3 \\
\hline $\mathrm{Mg}$ & 85.5 & 50.3 & 51.3 & 4.6 & 4.7 \\
\hline $\mathrm{Al}$ & 9.3 & 5.1 & 2.0 & - & - \\
\hline $\mathrm{Si}$ & - & - & - & - & - \\
\hline $\mathrm{P}$ & - & - & - & - & - \\
\hline $\mathrm{C}$ & - & - & & \\
\hline
\end{tabular}

samples is 560 ohms. The anodized sample with silicate additive has the highest absolute impedance that is around 2900 ohms. The other anodized samples have the absolute impedance of around 1100 ohms. However, at the low frequency region, all of the tested samples revealed the pitting corrosion sign. The imaginary impedance dropped below zero. In the 10 hour EIS test, Figure 3B, all of the tested samples absolute impedance reduced. The anodized sample with silicate additive remains the strongest in terms of corrosion resistance. The best possible fit equivalent circuit model and corresponding schematic anodized coating structure on AZ91D after localized pitting corrosion happened were listed in Figure $\mathbf{3 C}$ [23]. $R_{S}$ is the solution resistance, and CPE is the constant phase element. Compared to a pure capacitor, CPE is often used to describe an imperfect coating. The anodized coating has defects and pores on the surface, and CPE was more suitable than a capacitor in fitting the curves. The impedance of CPE, $\mathrm{Z}_{\mathrm{CPE}}$ is given by:

$$
Z_{\mathrm{CPE}}=Y 0^{-1}(j \omega)^{-m}
$$

Where $Y 0$ is a constant, $\omega$ is angular frequency, $j=(-1)^{1 / 2}$ and $\mathrm{m}$ is an exponential index that represents a dispersion of relaxation. When $m=1, C P E$ is a pure capacitor; when $m=$ $0, \mathrm{CPE}$ is a pure resistor. The values of $\mathrm{YO}$ from Equation (1) can be used to calculate the impedance of the CPE. The
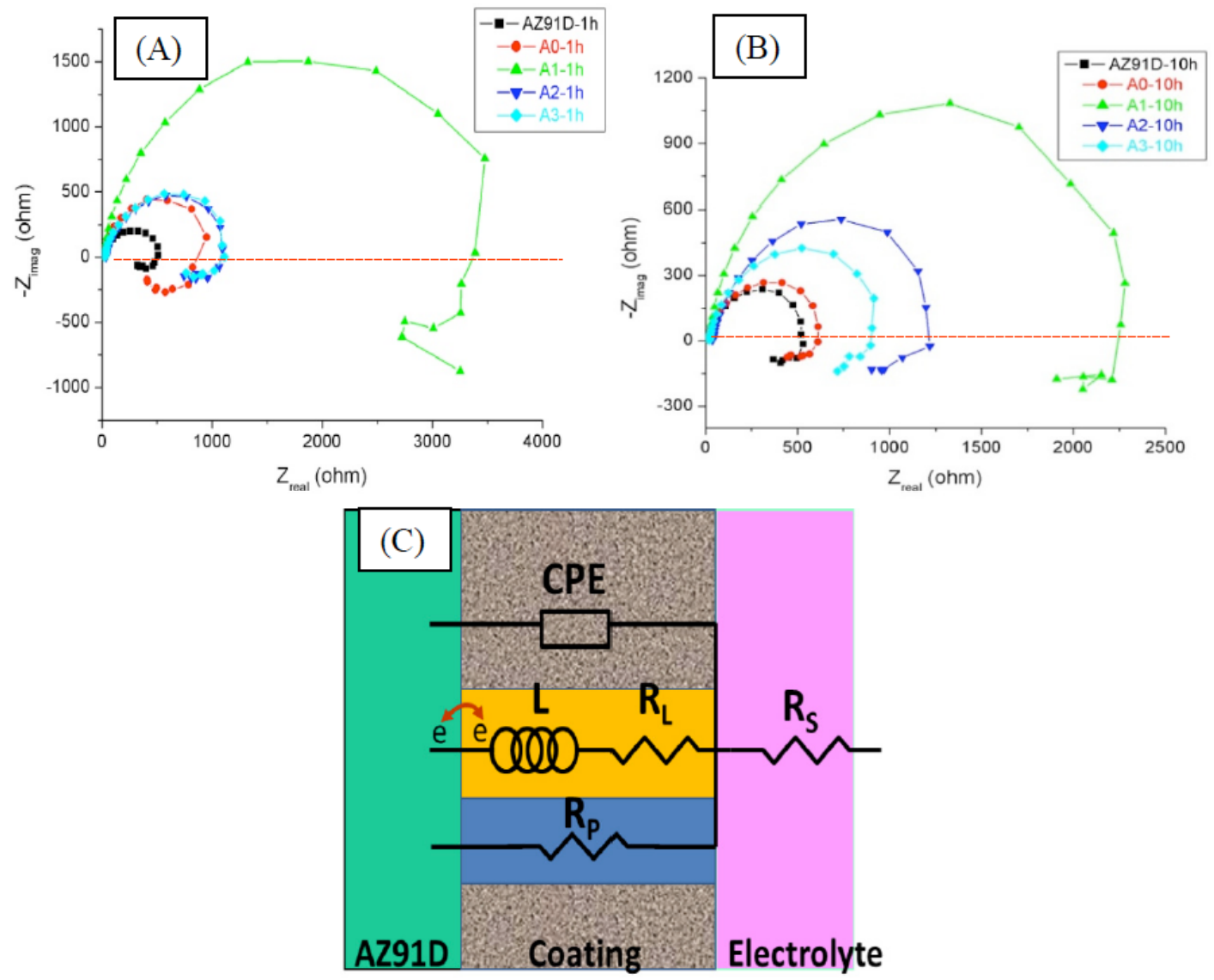

Figure 3: EIS of fresh and anodized AZ91D immersion in $0.15 \mathrm{M} \mathrm{NaCl}$ solution. (A) 1 hour; (B) 10 hours; (C) equivalent model circuit and corresponding schematic anodized coating structure on AZ91D after localized pitting corrosion. 
Table 3: EIS Fitting Parameters of Fresh AZ91D and A0, A1 for 1 and 10 hours Immersion in 0.15 M NaCl Solution

\begin{tabular}{|c|c|c|c|c|c|c|}
\hline & \multicolumn{3}{|c|}{$1 \mathrm{~h}$} & \multicolumn{3}{|c|}{$10 \mathrm{~h}$} \\
\hline & Fresh AZ91D & AO & A1 & Fresh AZ91D & AO & A1 \\
\hline $\mathrm{R}_{\mathrm{P}}(\Omega)$ & 528.1 & 993.7 & 3766 & 566.4 & 677.5 & 2511 \\
\hline $\mathrm{R}_{\mathrm{S}}(\Omega)$ & 14.11 & 13.86 & 16.19 & 13.61 & 13.99 & 16.14 \\
\hline$Y 0(\mu F)$ & 43.7 & 29.2 & 9.2 & 63.7 & 67.3 & 13.3 \\
\hline $\mathrm{m}$ & 0.856 & 0.916 & 0.903 & 0.881 & 0.862 & 0.899 \\
\hline$L(H)$ & 235.3 & 234.2 & 2962 & 435.2 & 460.1 & 2375 \\
\hline $\mathrm{R}_{\mathrm{L}}(\Omega)$ & 660.2 & 535.7 & 6686 & 746.1 & 1083 & 7291 \\
\hline
\end{tabular}

polarization resistance $\left(R_{P}\right)$ is that due to pores and defects in the coating. $L$ represents inductance. $L$ is due to the relaxation processes involving the dissolution of metal to ions leading to the formation of corrosion products with species from electrolyte at local places of corrosion. $R_{L}$ is inductanceintroduced resistance.

At high frequency, solution resistance $\left(R_{S}\right), C P E$ and polarization resistance $\left(R_{P}\right)$ dominated the structural current flow. At low frequency, since all of the samples showed inductance loops (curves below the red dashed lines in Figure $\mathbf{3 A}$ and $\mathbf{B}$ ), pitting corrosion occurred. $R_{S}$, an inductance $L$ and inductance introduced resistance, $R_{L}$, dominated the micro-structural current flow [12, 23-25]. The detailed fitting parameters are listed in Table 3. The untreated $\mathrm{Mg}$ alloy, the anodized sample without additive $(\mathrm{A} 0)$ and the anodized sample with silicate as additive (A1) are compared. During the 10 hour EIS test, before severe corrosion occurs, $R_{P}, \quad C P E$ and $R_{L}$ are the important electrochemical parameters in terms of evaluating the ability to protect against corrosion. In the 1 hour test, $\mathrm{A} 1$ and $\mathrm{A} 0$ show the polarization resistance of 3766 ohms and 993.7 ohms, respectively. The untreated AZ91D shows 528.1 ohms of polarization resistance. The $A 1$ sample shows the highest inductance introduced resistance of 6686 ohms followed by the 535.7 ohms of A0 and 660.2 ohms of untreated AZ91D. A1 also displays the lowest constant $\mathrm{Y} 0$ of $9.2 \mu \mathrm{F}$. In the 10 hour test, A1 still keeps the highest in polarization and inductance introduced resistances and the lowest in constant $Y 0$. In this study, adding silicate (A1) produced a better protective coating, in terms of resistance and capacitance.

The DC polarization test as shown in Figure 4, and the detailed fitting parameters listed Table 4, carried out after 10 hours immersion in $0.15 \mathrm{M} \mathrm{NaCl}$ solution. The test was run on fresh AZ91D, A0 and A1. Anodization not only increased the corrosion potential but also reduced the corrosion rate compared to that of fresh AZ91D which is 78.01 mils per year. $A 1$, with a corrosion rate of 5.79 mils per year, had the lowest of all.

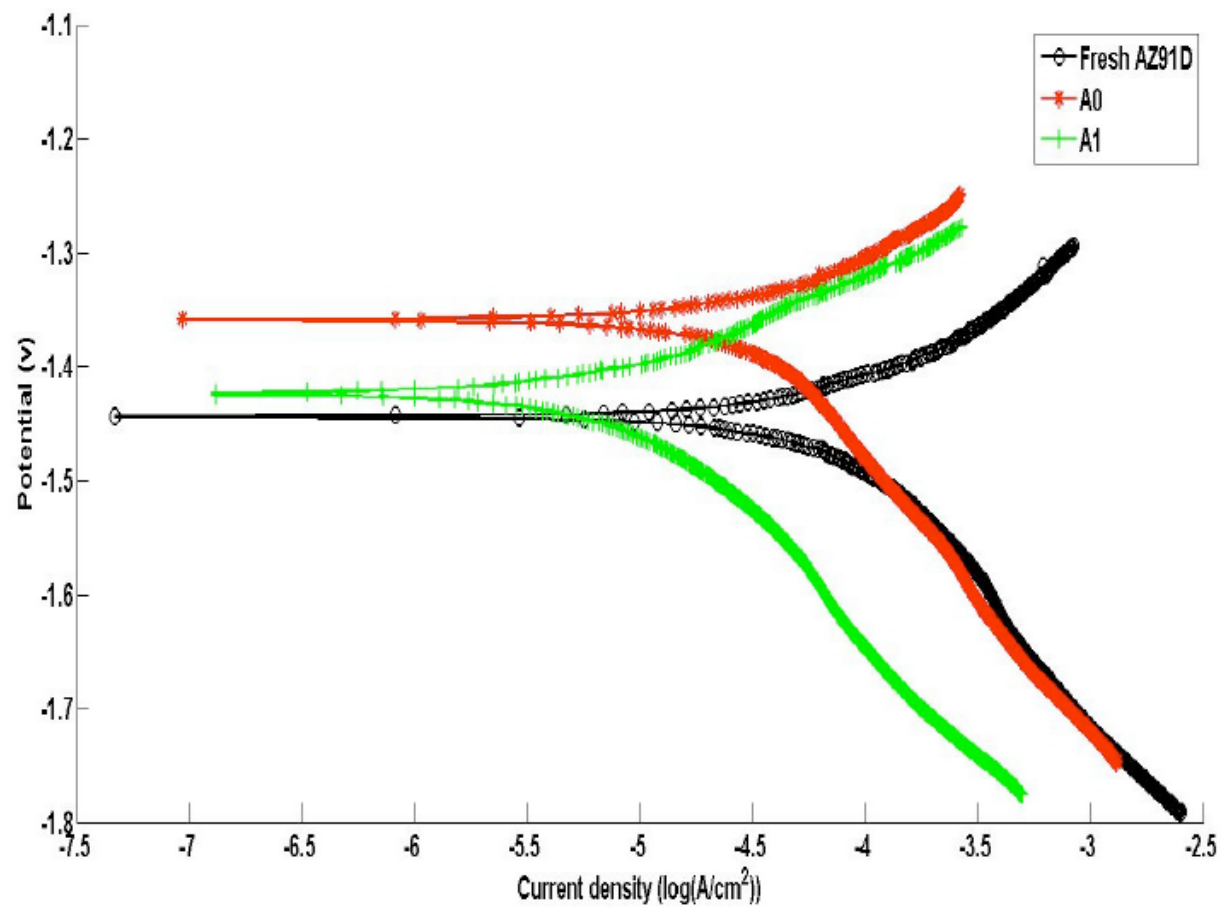

Figure 4: DC polarization test on fresh AZ91D, $A 0$ and $A 1$ immersion in $0.15 \mathrm{M} \mathrm{NaCl}$ solution. 
Journal of Coating Science and Technology, 2014, Volume 1, No. 1

Table 4: DC Polarization Fitting Parameters of Fresh AZ91D and A0, A1, A1-3 for 10 hours Immersion Time in 0.15 M NaCl Solution

\begin{tabular}{|c|c|c|c|c|}
\hline & Fresh AZ91D & A0 & A1 & A1-3 \\
\hline $\mathrm{E}_{\text {corr }}$ (V vs Ref) & -1.44 & -1.36 & -1.42 & -1.37 \\
\hline $\mathrm{I}_{\text {corr }}\left(\mathrm{uA} / \mathrm{cm}^{2}\right)$ & 43.12 & 15.15 & 3.13 & 1.17 \\
\hline Corrosion Rate (mills per year (mpy)) & 78.01 & 27.55 & 5.79 & 2.01 \\
\hline
\end{tabular}

\subsection{The Effects of $\mathrm{Na}_{2} \mathrm{SiO}_{3}$ Concentration on Anodization}

The effects of the concentration of silicate on the coating morphology are shown in Figure 5. The silicate concentrations were $0.05 \mathrm{M}(\mathrm{A}), 0.15 \mathrm{M}(\mathrm{B})$ and $0.5 \mathrm{M}(\mathrm{C})$ to $3 \mathrm{M}(\mathrm{D})$ added into the $2 \mathrm{M} \mathrm{NaOH}$ electrolyte. The rough areas appeared to be larger in $0.15 \mathrm{M}$ than in $0.05 \mathrm{M}$. However, from $0.15 \mathrm{M}$ to $0.5 \mathrm{M}$, the morphology changed dramatically. At $0.5 \mathrm{M}$ addition, the surface became relatively uniform compared to the smooth-rough combination morphology. However, when $3 \mathrm{M}$ was added, the morphology changed greatly, from appearing uniform-loose $(0.5 \mathrm{M})$ to uniform-dense $(3 \mathrm{M})$. The pore size and porosity were both reduced at $3 \mathrm{M}$, and the surface chemical elements changed with varied amounts of silicate. In Table 5, from $0.05 \mathrm{M}$ to 3 $\mathrm{M}$, the $\mathrm{O}, \mathrm{Si}$, as well as $\mathrm{Na}$ concentration increased, and $\mathrm{Mg}$ and $\mathrm{Al}$ concentrations decreased. The increased $\mathrm{O}$ might be due to the formation of $\mathrm{Mg}_{2} \mathrm{SiO}_{4}[16,19]$, instead of $\mathrm{MgO}$ or $\mathrm{Mg}(\mathrm{OH})_{2}$ 2. Since the $\mathrm{Mg}(\mathrm{OH})_{2}$ and water concentrations were the same only the silicate concentration was varied. The increase of $\mathrm{Na}$ might be due to the $\mathrm{Na}^{+}$physically attached from electrolyte in the form of $\mathrm{Na}_{2} \mathrm{SiO}_{3}$.

The silicate concentration also affected the thickness of the coating. When $0.05 \mathrm{M}$ and $0.15 \mathrm{M}$ were added, the coatings were barely seen on Figure $6 \mathrm{~A}$ and $\mathrm{B}$, respectively. However, as seen in Figure $\mathbf{6 C}$, when the silicate concentration reached $0.5 \mathrm{M}$, the coating was obvious at $15 \mu \mathrm{m}$ thick. The coating also had some pores and was not uniform. When $3 \mathrm{M}$ silicate was added, however, the coating appeared to be uniformly thick at $23 \mu \mathrm{m}$, with a dense structure.

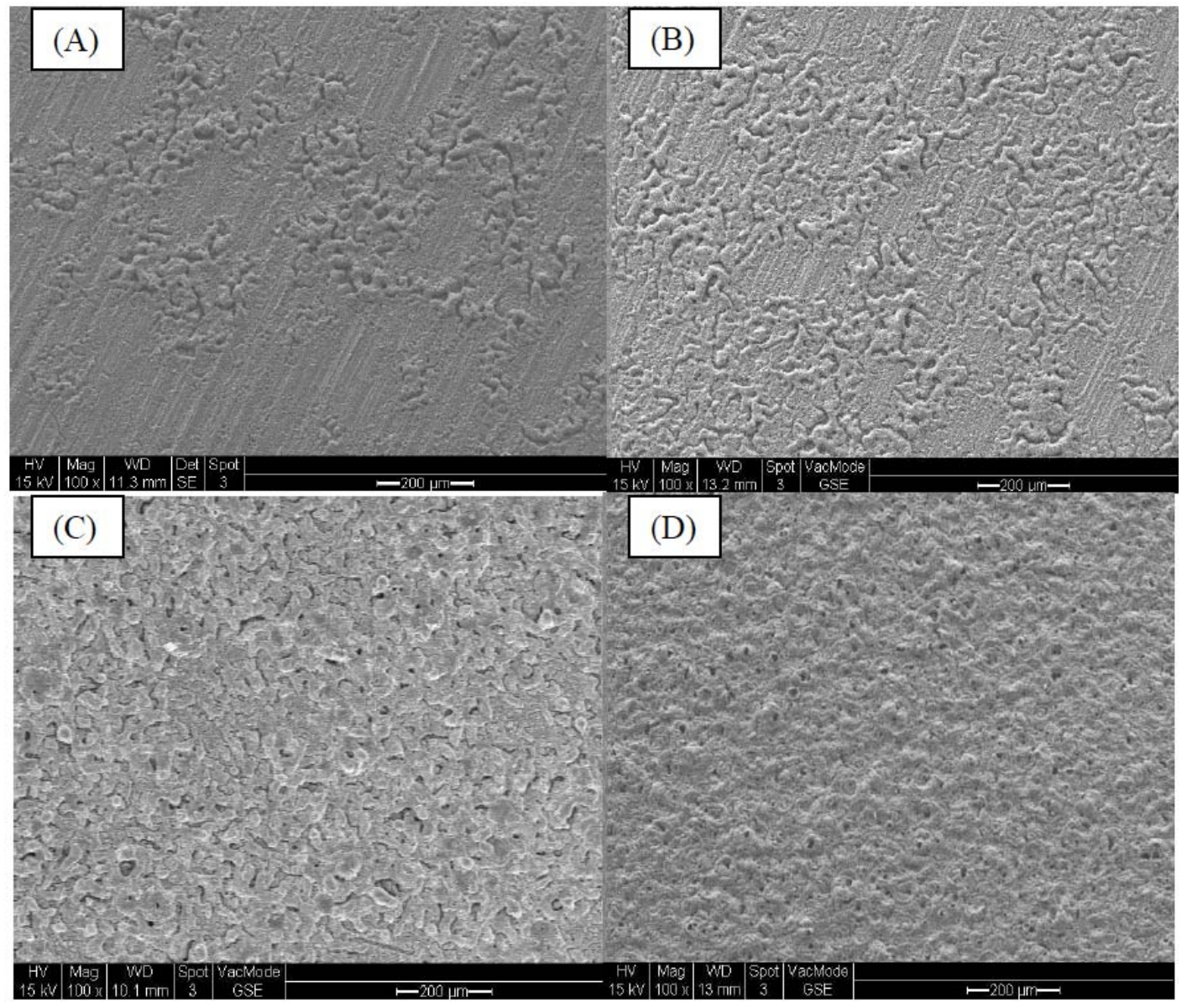

Figure 5: SEM of anodized AZ91D in various silicate concentration electrolytes. (A) $2 \mathrm{M} \mathrm{NaOH}+0.05 \mathrm{M} \mathrm{Na}_{2} \mathrm{SiO}_{4}(\mathrm{~A} 1) ;(B) 2 \mathrm{M} \mathrm{NaOH}+0.15 \mathrm{M}$ $\mathrm{Na}_{2} \mathrm{SiO}_{4}(\mathrm{~A} 1-1) ;\left(\right.$ C) $2 \mathrm{M} \mathrm{NaOH}+0.5 \mathrm{M} \mathrm{Na}_{2} \mathrm{SiO}_{4}$ (A1-2); (D) $2 \mathrm{M} \mathrm{NaOH}+3 \mathrm{M} \mathrm{Na}_{2} \mathrm{SiO}_{4}$ (A1-3). 
Table 5: Detailed Surface Elements Information in Atom Percentage of Anodized AZ91D in Various Silicate Concentration Electrolytes. $2 \mathrm{M} \mathrm{NaOH}+0.05 \mathrm{M} \mathrm{Na}_{2} \mathrm{SiO}_{4}$ (A1); $2 \mathrm{M} \mathrm{NaOH}+0.15 \mathrm{M} \mathrm{Na}_{2} \mathrm{SiO}_{4}$ (A1-1); $2 \mathrm{M} \mathrm{NaOH}+0.5 \mathrm{M} \mathrm{Na}_{2} \mathrm{SiO}_{4}(\mathrm{~A} 1-2) ; 2 \mathrm{M}^{2}$ $\mathrm{NaOH}+3 \mathrm{M} \mathrm{Na}_{2} \mathrm{SiO}_{4}(\mathrm{~A} 1-3)$

\begin{tabular}{|c|c|c|c|c|}
\hline & A1 & A1-1 & A1-2 & A1-3 \\
\hline \hline $\mathrm{O}$ & 43.2 & 45.0 & 52.6 & 51.8 \\
\hline $\mathrm{Na}$ & - & 1.8 & 26.5 & 16.7 \\
\hline $\mathrm{Mg}$ & 51.3 & 46.1 & 1.9 & 9.4 \\
\hline $\mathrm{Al}$ & 3.5 & 2.6 & 12.3 & 1.1 \\
\hline $\mathrm{Si}$ & 2.0 & 4.5 & & 21.0 \\
\hline
\end{tabular}

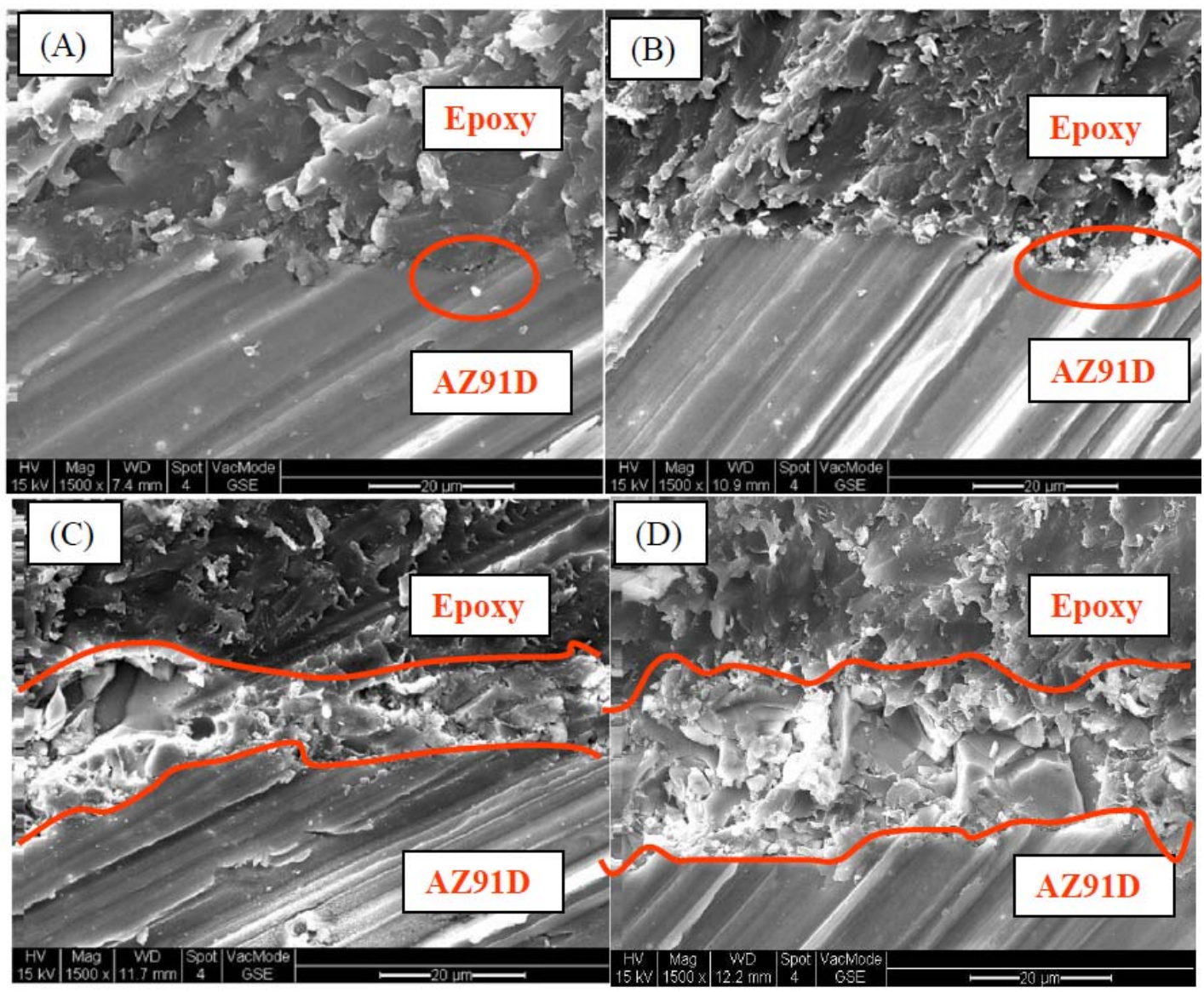

Figure 6: Cross-sections of of anodized AZ91D in various silicate concentration electrolytes. (A) $2 \mathrm{M} \mathrm{NaOH}+0.05 \mathrm{M} \mathrm{Na}_{2} \mathrm{SiO}_{4}(\mathrm{~A} 1)$; (B) $2 \mathrm{M}$ $\mathrm{NaOH}+0.15 \mathrm{M} \mathrm{Na}_{2} \mathrm{SiO}_{4}$ (A1-1); (C) $2 \mathrm{M} \mathrm{NaOH}+0.5 \mathrm{M} \mathrm{Na}_{2} \mathrm{SiO}_{4}$ (A1-2); (D) $2 \mathrm{M} \mathrm{NaOH}+3 \mathrm{M} \mathrm{Na}_{2} \mathrm{SiO}_{4}$ (A1-3).

DC polarization on samples of $A 1$ and $A 1-3$ was carried out after 10 hour immersion. The polarization curve is listed as Figure 7 and the fitting parameters are included in Table 4. A1-3 showed better corrosion protective ability in terms of the lower corrosion rate. The corrosion rate of $A 1-3$ was 2.01 mpy, but it was 5.79 mpy for A1. A1-3 also increased the corrosion potential compared to $\mathrm{A} 1$ from $-1.42 \mathrm{~V}$ to $-1.37 \mathrm{~V}$.

\section{DISCUSSION}

The primary oxy-salts played an important role in anodizing AZ91D in alkaline electrolyte, in terms of the terminating voltage and anodizing behavior. The $\mathrm{A} 0, \mathrm{~A} 2$, and $\mathrm{A} 3$ voltages first jumped and then dropped immediately due to a naturally formed magnesium oxide layer on the surface. At the start of anodization, the immediate effect of the increase in voltage was to break this first passivity film. However, the A1 voltage continued to increase, which indicated that the coating thickness and resistance also continued to increase. Adding silicate by forming $\mathrm{Mg}_{2} \mathrm{SiO}_{4}$, compared to phosphate and carbonate by forming $\mathrm{MgO} / \mathrm{Mg}(\mathrm{OH})_{2}$, helped the system build a thicker coating [4]. In the EDX measurements on $A 0$, $A 1, A 2$ and $A 3$, only Si was found in the coating. $P$ and $C$ were absent. This indicated that the high terminating 


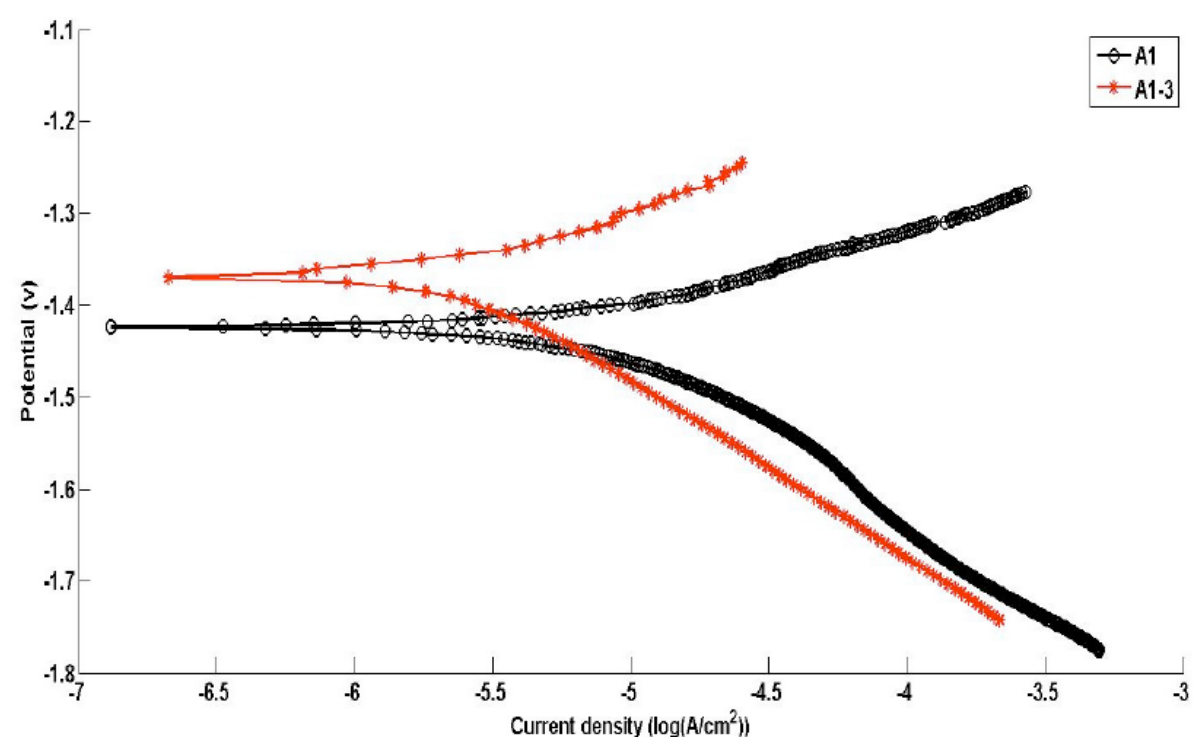

Figure 7: $\mathrm{DC}$ polarizatioin of $\mathrm{A} 1\left(2 \mathrm{M} \mathrm{NaOH}+0.05 \mathrm{M} \mathrm{Na}_{2} \mathrm{SiO}_{4}\right)$ and $\mathrm{A} 1-3\left(2 \mathrm{M} \mathrm{NaOH}+3 \mathrm{M} \mathrm{Na}_{2} \mathrm{SiO}_{4}\right)$ after 10 hours immersion in $0.15 \mathrm{M} \mathrm{NaCl}$ solution.

anodization voltage might be critical to the supportive functional oxy-salt formation. On the other hand, certain primary oxy-salts can help the thick coating to form and support high terminating voltage anodization. Therefore, selecting and adding the primary oxy-salts to the alkaline electrolyte is critical for different applications.

Our previous studies showed that the silicate could also increase the molar volume of the coating by forming $\mathrm{Mg}_{2} \mathrm{SiO}_{4}$ [4]. Contact angle measurements were made. The contact angle figures are listed in Figure 8. And the summarized angles are in Table 6. The fresh AZ91D had a contact angle of $68.9^{\circ}$. A0, A2, A3 had no contact angles. Since A0, A2 and A3 coating generally had a ceramic composition of $\mathrm{MgO} / \mathrm{Mg}$ $(\mathrm{OH})_{2}$; it lowered the coating hydrophobicity compared to the metal substrate. Moreover, the molar volume of $\mathrm{MgO}$ is smaller than that of $\mathrm{Mg}$ and this would cause the surface to shrink, generating a porous structure. However, A1 had a contact angle of $44.3^{\circ}$ of, and the presence of $\mathrm{Si}$ in the

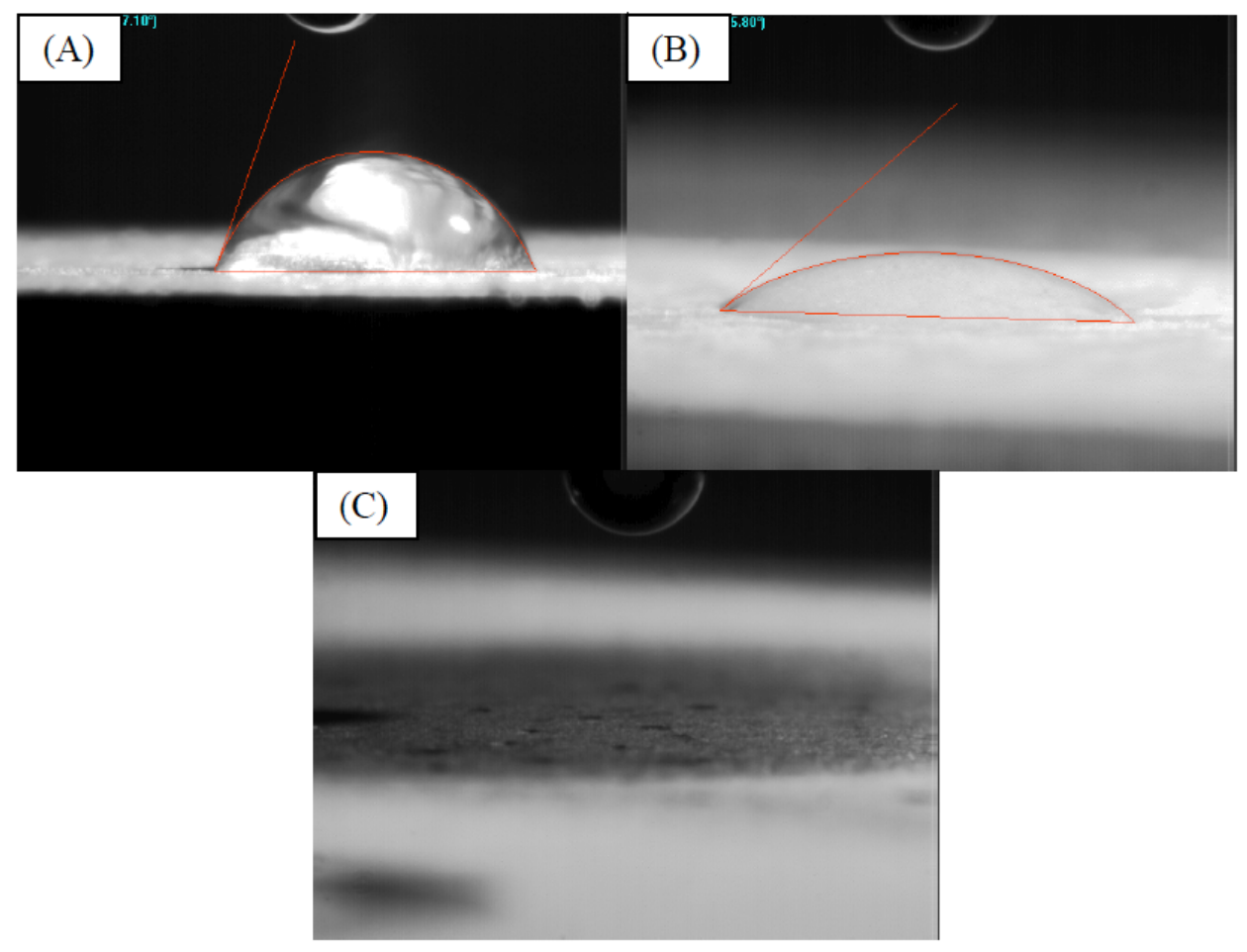

Figure 8: Contact angle images of anodized coatings from different primary oxy-salts addition electrolytes at $10 \mathrm{~mA} / \mathrm{cm}^{2}$ for $30 \mathrm{~min}$. (A) Fresh AZ91D; (B) $2 \mathrm{M} \mathrm{NaOH}+0.05 \mathrm{M} \mathrm{Na}_{2} \mathrm{SiO}_{3}(\mathrm{~A} 1)$; (C) $2 \mathrm{M} \mathrm{NaOH}(\mathrm{A} 0)$; $2 \mathrm{M} \mathrm{NaOH}+0.05 \mathrm{M} \mathrm{Na}_{3} \mathrm{PO}_{4}(\mathrm{~A} 2) ; 2 \mathrm{M} \mathrm{NaOH}+0.05 \mathrm{M} \mathrm{Na}_{2} \mathrm{CO}_{3}(\mathrm{~A} 3$ ). 
coating was the only difference from $\mathrm{A} 0, \mathrm{~A} 2$ and $\mathrm{A} 3 . \mathrm{Mg}_{2} \mathrm{SiO}_{4}$ might contribute to this difference. $\mathrm{Mg}_{2} \mathrm{SiO}_{4}$ has a higher molar volume, and it can help the coating smooth the shrinkage caused by formation of $\mathrm{MgO}[4,20,26]$. Siloxane (O-Si-O-) $\left(\mathrm{SiO}_{2}\right)$ x network deposited on the coating physically from the electrolyte might also increase the coating hydrophobicity [27-30].

Table 6: Contact Angle of Anodized Coatings from Different Primary Oxy-Salts Addition Electrolytes at 10 $\mathrm{mA} / \mathrm{cm}^{2}$ for $30 \mathrm{~min}$. Fresh AZ91D; $2 \mathrm{M} \mathrm{NaOH}(\mathrm{A0}) ; 2 \mathrm{M}$ $\mathrm{NaOH}+0.05 \mathrm{M} \mathrm{Na}_{2} \mathrm{SiO}_{3}($ A1); $2 \mathrm{M} \mathrm{NaOH}+0.05 \mathrm{M}$ $\mathrm{Na}_{3} \mathrm{PO}_{4}(\mathrm{~A} 2) ; 2 \mathrm{M} \mathrm{NaOH}+0.05 \mathrm{M} \mathrm{Na}_{2} \mathrm{CO}_{3}(\mathrm{~A} 3)$

\begin{tabular}{|c|c|}
\hline & Contact angle \\
\hline \hline AZ91D & $68.9^{\circ}$ \\
\hline A0 & 0 \\
\hline A1 & $44.3^{\circ}$ \\
\hline A2 & 0 \\
\hline A3 & 0 \\
\hline
\end{tabular}

\section{CONCLUSIONS}

Silicate, phosphate, and carbonate primary oxy-salts were added to a sodium hydroxide alkaline electrolyte used for anodization. SEM and EDX characterized the surface. Electrochemical tests in $0.15 \mathrm{M} \mathrm{NaCl}$ solution were used to evaluate the anodized coating. The results and findings obtained from this work are listed as follows:

1) Different oxy-salts could lead to different anodization behavior.

2) Adding silicate increased the anodization terminating voltage, generated sparks, and helped the system to build a thicker and more corrosion resistant coating.

3) A high concentration of silicate in the electrolyte, but below its solubility limit, yielded a smooth film with small pore size, low porosity, and a thick, corrosion resistant coating.

\section{ACKNOWLEDGEMENTS}

This work is sponsored by the National Science Foundation (NSF) Engineering Research Center (ERC) for Revolutionizing Metallic Biomaterials (RMB). This support is gratefully acknowledged.

\section{REFERENCES}

[1] Witte F, Fischer J, Nellesen J, et al. In vitro and in vivo corrosion measurements of magnesium alloys. Biomaterials 2006; 27(7): 101318.

http://dx.doi.org/10.1016/j.biomaterials.2005.07.037

[2] Witte $F$, Kaese $V$, Haferkamp $\mathrm{H}$, et al. In vivo corrosion of four magnesium alloys and the associated bone response. Biomaterials 2005; 26(17): 3557-63.

http://dx.doi.org/10.1016/i.biomaterials.2004.09.049
Zeng RC, Dietzel W, Witte F, Hort N, Blawert C. Progress and challenge for magnesium alloys as biomaterials. Adv Eng Mater 2008; 10(8): B3-B14.

http://dx.doi.org/10.1002/adem.200800035

[4] Xue D, Yun Y, Schulz MJ, Shanov V. Corrosion protection of biodegradable magnesium implants using anodization. Mater Sci Eng C 2011; 31(2): 215-23. http://dx.doi.org/10.1016/i.msec.2010.08.019

[5] Hiromoto S, Shishido T, Yamamoto A, Maruyama N, Somekawa H, Mukai T. Precipitation control of calcium phosphate on pure magnesium by anodization. Corrosion Sci 2008; 50(10): 2906-13. http://dx.doi.org/10.1016/i.corsci.2008.08.013

[6] Khaselev O, Yahalom J. The anodic behavior of binary Mg-Al alloys in $\mathrm{KOH}$-aluminate solutions. Corrosion Sci 1998; 40(7): 1149-60. http://dx.doi.org/10.1016/S0010-938X(98)00019-5

[7] Mizutani Y, Kim SJ, Ichino R, Okido M. Anodizing of Mg alloys in alkaline solutions. Surface Coat Technol 2003; 169: 143-46. http://dx.doi.org/10.1016/S0257-8972(03)00214-7

[8] Li LL, Cheng YL, Wang HM, Zhang Z. Anodization of AZ91 magnesium alloy in alkaline solution containing silicate and corrosion properties of anodized films. Trans Nonferrous Metals Soc China 2008; 18(3): 722-27.

http://dx.doi.org/10.1016/S1003-6326(08)60124-7

[9] Ono S, Miyake M, Asoh H. Effects of formation voltage and electrolyte ions concentration on the structure and passivity of anodic films on magnesium. J Jpn Instit Light Metals 2004; 54(11): 544-50. http://dx.doi.org/10.2464/iilm.54.544

[10] Hsiao HY, Tsai WT. Characterization of anodic films formed on AZ91D magnesium alloy. Surf Coat Technol 2005; 190(2-3): 299-308. http://dx.doi.org/10.1016/.surfcoat.2004.03.010

[11] Park IS, Jang YS, Kim Y K, Lee MH, Yoon JM, Bae TS. Surface characteristics of AZ91D alloy anodized with various conditions. Surf Interf Anal 2008; 40(9): 1270-77.

http://dx.doi.org/10.1002/sia.2876

[12] Barchiche CE, Rocca E, Juers C, Hazan J, Steinmetz J. Corrosion resistance of plasma-anodized AZ91D magnesium alloy by electrochemical methods. Electrochim Acta 2007; 53(2): 417-25. http://dx.doi.org/10.1016/i.electacta.2007.04.030

[13] Ghasemi A, Raja VS, Blawert C, Dietzel W, Kainer KU. The role of anions in the formation and corrosion resistance of the plasma electrolytic oxidation coatings. Surf Coat Technol 2010; 204(9-10): 1469-78.

http://dx.doi.org/10.1016/i.surfcoat.2009.09.069

[14] Wen Q, Cao FH, Shi YY, Zhang Z, Zhang JQ. The effect of phosphate on MAO of AZ91D magnesium using AC power source. Materials and Corrosion-Werkstoffe Und Korrosion 2008; 59(10): 819-24. http://dx.doi.org/10.1002/maco.200804169

[15] Salman S, Ichino R, Okido M. Influence of calcium hydroxide and anodic solution temperature on corrosion property of anodising coatings formed on AZ31 Mg alloys. Surf Eng 2008; 24(3): 242-45. http://dx.doi.org/10.1179/174329408X282578

[16] Birss V, Xia S, Yue R, Rateick RG. Characterization of oxide films formed on Mg-based WE43 alloy using AC/DC anodization in silicate solutions. J Electrochem Soc 2004; 151(1): B1-B10.

http://dx.doi.org/10.1149/1.1629095

[17] Zhang YJ, Yan CW, Wang FH, Lou HY, Cao CN. Study on the environmentally friendly anodizing of AZ91D magnesium alloy. Surf Coat Technol 2002; 161(1): 36-43. http://dx.doi.org/10.1016/S0257-8972(02)00342-0

[18] Duan HP, Yan CW, Wang FH. Growth process of plasma electrolytic oxidation films formed on magnesium alloy AZ91D in silicate solution. Electrochim Acta 2007; 52(15): 5002-5009. http://dx.doi.org/10.1016/i.electacta.2007.02.021

[19] Guo HF, An MZ, Huo HB, Xu S, Wu LJ. Microstructure characteristic of ceramic coatings fabricated on magnesium alloys by micro-arc oxidation in alkaline silicate solutions. Appl Surf Sci 2006; 252(22): 7911-16.

http://dx.doi.org/10.1016/i.apsusc.2005.09.067

[20] Wu HL, Cheng YL, Li LL, Chen ZH, Wang HM, Zhang Z. The anodization of ZK60 magnesium alloy in alkaline solution containing silicate and the corrosion properties of the anodized films. Appl Surf Sci 2007; 253(24): 9387-94.

http://dx.doi.org/10.1016/j.apsusc.2007.05.085

[21] Fukuda $\mathrm{H}$, Matsumoto $\mathrm{Y}$. Effects of $\mathrm{Na2SiO} 3$ on anodization of $\mathrm{Mg}-\mathrm{Al}-$ $\mathrm{Zn}$ alloy in $3 \mathrm{M} \mathrm{KOH}$ solution. Corrosion Sci 2004; 46(9): 2135-42. http://dx.doi.org/10.1016/i.corsci.2004.02.001

[22] Chai LY, Yu X, Yang ZH, Wang YY, Okido M. Anodizing of 
magnesium alloy AZ31 in alkaline solutions with silicate under continuous sparking. Corrosion Sci 2008; 50(12): 3274-79. http://dx.doi.org/10.1016/i.corsci.2008.08.038

[23] Zhao M, Wu S, An P, Luo J. Study on the deterioration process of a chromium-free conversion coating on AZ91D magnesium alloy in $\mathrm{NaCl}$ solution. Appl Surf Sci 2006; 253(2): 468-75.

http://dx.doi.org/10.1016/i.apsusc.2005.12.122

[24] Liang J, Srinivasan PB, Blawert C, Dietzel W. Influence of chloride ion concentration on the electrochemical corrosion behaviour of plasma electrolytic oxidation coated AM50 magnesium alloy. Electrochim Acta 2010; 55(22): 6802-11.

http://dx.doi.org/10.1016/i.electacta.2010.05.087

[25] Duan H, Du K, Yan C, Wang F. Electrochemical corrosion behavior of composite coatings of sealed MAO film on magnesium alloy AZ91D. Electrochim Acta 2006; 51(14): 2898-908.

http://dx.doi.org/10.1016/j.electacta.2005.08.026

[26] Zhang YJ, Yan CW. Development of anodic film on Mg alloy AZ91D. Surf Coat Technol 2006; 201(6): 2381-86. http://dx.doi.org/10.1016/j.surfcoat.2006.04.015

[27] van Ooij WJ, Zhu D, Stacy M, Seth A, Mugada T, Gandhi J, Puomi P. Corrosion Protection Properties of Organofunctional Silanes--An Overview. Tsinghua Sci Technol 2005; 10(6): 639-64 http://dx.doi.org/10.1016/S1007-0214(05)70134-6

[28] Montemor MF, Ferreira MGS. Analytical and microscopic characterisation of modified bis-[triethoxysilylpropyl] tetrasulphide silane films on magnesium AZ31 substrates. Progr Organ Coat 2007; 60(3): 228-37.

http://dx.doi.org/10.1016/i.porgcoat.2007.07.019

[29] Montemor MF, Ferreira MGS. Electrochemical study of modified bis[triethoxysilylpropyl] tetrasulfide silane films applied on the AZ31 Mg alloy. Electrochim Acta 2007; 52(27): 7486-95. http://dx.doi.org/10.1016/j.electacta.2006.12.086

[30] Kim J, Wong KC, Wong PC, Kulinich SA, Metson JB, Mitchell KAR Characterization of AZ91 magnesium alloy and organosilane adsorption on its surface. Appl Surf Sci 2007; 253(9): 4197-207. http://dx.doi.org/10.1016/i.apsusc.2006.09.030 